Research Article

\title{
Genetic polymorphisms of Interleukin-18 are not associated with allograft function in kidney transplant recipients
}

Wenna Gleyce Araújo do Nascimento ${ }^{1}$, Daiani Alves Cilião ${ }^{2}$, Julieta Genre ${ }^{3}$, Dikson Dibe Gondim ${ }^{1}$, Renata Gomes Alves ${ }^{4}$, Neife Deghaide Hassan ${ }^{2}$, Francisco Pignataro Lima ${ }^{5}$, Maurício Galvão Pereira ${ }^{6}$, Eduardo Antônio Donadi ${ }^{2}$ and Janaina Cristiana de Oliveira Crispim ${ }^{1}$

${ }^{1}$ Departamento de Análises Clínicas e Toxicológicas, Universidade Federal do Rio Grande do Norte, Natal, RN, Brazil.

${ }^{2}$ Departamento de Medicina Clínica, Faculdade de Medicina de Ribeirão Preto, Universidade de São Paulo, Ribeirão Preto, SP, Brazil.

${ }^{3}$ Programa de Pós-Graduação em Ciências Farmacêuticas, Universidade Federal do Rio Grande do Norte, Natal, RN, Brazil.

${ }^{4}$ Hemocentro do Rio Grande do Norte, Natal, RN, Brazil.

${ }^{5}$ Departamento de Patologia, Universidade Federal do Rio Grande do Norte, Natal, RN, Brazil.

${ }^{6}$ Departamento de Medicina Integrativa, Universidade Federal do Rio Grande do Norte, Natal, RN, Brazil.

\begin{abstract}
Interleukin 18 (IL-18) is a proinflammatory cytokine that plays a role in host defense by upregulating both innate and acquired immune responses. Analysis of IL 18 polymorphisms may be clinically important since their roles have been recognized in a variety of inflammatory and autoimmune disorders. However, the role of this cytokine polymorphisms in kidney transplant still remains unclear. In this study, we evaluated the associations between IL18 polymorphisms and graft function assessed by creatinine clearance in kidney transplant recipients. A total of 82 kidney transplant recipients and 183 healthy controls were enrolled, and frequencies of alleles, genotypes and haplotypes for IL18 polymorphisms were determined and compared with creatinine clearance. The -607C/A (rs1946518) and -137C/G (rs187238) variant alleles in the IL18 gene were determined by polymerase chain reaction. In our study, no significant association was found between the $I L 18$ variants and creatinine clearance $(p>0.05)$. Nonetheless, polymorphism analysis revealed an increase in the frequency of the IL18 major haplotype - $607 \mathrm{C} /-137 \mathrm{G}$ in kidney transplant patients (odds ratio $2.57,95 \%$ confidence interval $1.45-4.55, p=0.0014$ ). Finally, we found that $I L 18$ polymorphisms did not influence the renal function and that IL 18 haplotype -607C/-137G seems to be associated with kidney transplant recipients.
\end{abstract}

Keywords: IL-18, -607C/A, -137C/G, kidney transplant.

Received: November 18, 2013; Accepted: February 25, 2014.

\section{Introduction}

Kidney transplantation is a widely accepted treatment for end-stage renal failure, improving life quality and extending patients survival time. In Brazil, the number of patients on waiting lists for kidney transplantation was about 21,686 in the second semester of 2012, corresponding to $24 \%$ of a total of nearly 90,000 patients in dialysis treatment (Solez et al., 2008). Despite all advances in the development of immunosuppressive drugs and the introduction of supportive therapies aimed to decrease acute rejection

Send correspondence to Janaina Cristiana de Oliveira Crispim. Departamento de Análises Clínicas e Toxicológicas, Universidade Federal do Rio Grande do Norte, Rua Gal. Gustavo Cordeiro de Farias s/n, 59012-570 Natal, RN, Brazil. E-mail: janacrispimfre@gmail.com. incidence, several poorly elucidated factors still affect the success of a kidney transplant, leading to a progressive deterioration of the renal function and graft loss.

In synergy with IL-12, IL-18 stimulates the release of IFN- $\gamma$ by T and B cells, increasing the cytolytic activity of NK cells (Nakamura et al., 1989; Okamura et al., 1995; Micallef et al., 1996; Yoshimoto et al., 1998) and inducing Th1 or Th2 responses, depending on the underlying immunological milieu (Reddy, 2004). IL-18 levels have been reported to be abnormal in some inflammatory and autoimmune diseases (Haas et al., 2005; Novak et al., 2005; Imboden et al., 2006; Thompson and Huphries, 2007). In a murine model of kidney rejection, IL-18 induces several pathways of inflammation when IL18 and IL18R gene expression are upregulated in allografts (Wy- 
burn et al., 2006). Furthermore, increased levels of IL-18 produced by intra-graft macrophages were observed during acute rejection in a rat model (Wyburn et al., 2005). In humans, IL-18 is upregulated in patients during kidney allograft rejection, is expressed in the allograft microenvironment and increased IL-18 serum levels are detected in these patients (Striz et al., 2005). As a corollary, decreased IL-18 levels have been associated with decreased serum creatinine levels in kidney transplant recipients (Parikh et al., 2004).

The IL18 gene has at least two functional polymorphisms affecting the cytokine production and only few studies have evaluated the association of IL18 polymorphisms with kidney allotransplantation (Kolesar et al., 2007; Kim et al., 2008; Mittal et al., 2011). In this study, we hypothesized that the genetic variability at the IL18 gene was associated with kidney allograft function. Considering that creatinine clearance $(\mathrm{CrCl})$ is considered to be a gold standard marker for renal function, we evaluated the association between $I L 18-607 \mathrm{C} / \mathrm{A}$ (rs1946518) and $-137 \mathrm{C} / \mathrm{G}$ (rs187238) single nucleotide polymorphisms (SNPs) and graft function as assessed by $\mathrm{CrCl}$ in kidney transplant recipients.

\section{Material and Methods}

\section{Patients and controls}

A total of 82 kidney transplant recipients (54 men and 28 women, mean age $38.40 \pm 13.21$ years) were enrolled from 2010 to 2011 at the Hospital Universitário Onofre Lopes in Natal, in northeastern Brazil. All patients who were attended at the hospital due to disorders in creatinine serum were enrolled, being that 23 of the recruited patients were found in rejection episode during the analysis whereas 59 had no rejection.

Diagnosis of kidney rejection in transplanted patients was realized by histopathological analyses of graft biopsy according to Banff 07 classification (Solez et al., 2008). Biopsies were done on the basis of renal dysfunction, whether worsening or not improving in creatinine levels, i.e. no creatinine stabilization. In the absence of biopsy indication, only laboratory tests were collected to monitor the graft function.

As controls of our study, 183 healthy sex- and agematched individuals (123 men and 60 women, mean age $30.33 \pm 8.19$ years) were enrolled. These subjects were bone marrow donors at the Hospital Universitário Onofre Lopes and had no known infectious, chronic or autoimmune disorders and neither had kidney diseases and/or undergone transplantation.

This study was approved by the ethical committee of Hospital Universitário Onofre Lopes, Universidade Federal do Rio Grande do Norte, and signed informed consent forms were obtained from all participants.

\section{Creatinine Clearance $(\mathrm{CrCl})$ determination}

We evaluated the kidney graft function during a follow-up period of 1 month, 3 months and 6 months after transplantation. The renal function was assessed by determining creatinine clearance levels using the CockroftGault formula calculated as ((140 - age) $\mathrm{x}$ weight $) / 72 \mathrm{x}$ (serum creatinine in $\mathrm{mg} / \mathrm{dL}) \times(0.85$ if female) (Cockcroft and Gault, 1976).

\section{DNA isolation and amplification of IL18 promoter polymorphisms}

DNA was extracted from peripheral blood leukocytes by Miller's salting out procedure (Miller et al., 1988). IL18 promoter polymorphisms were evaluated by the polymerase chain reaction (PCR). PCR was done in a final volume of $10 \mu \mathrm{L}$ containing $100 \mathrm{ng}$ of genomic DNA, 3 pmol of two primers (a common one and the allele-specific one), 2 pmol of each control primer, $0.25 \mathrm{mM}$ dNTP (Pharmacia Biotech, Paris, France), $1.5 \mathrm{mM} \mathrm{MgCl2}, 0.75 \mathrm{U}$ of Taq DNA polymerase (Invitrogen, Carlsbad, CA) and 1x PCR buffer $(0.2 \mathrm{M}$ Tris-HCl, $\mathrm{pH} 8.5,0.5 \mathrm{M} \mathrm{KCl})$. The cycling conditions were $3 \mathrm{~min}$ at $94^{\circ} \mathrm{C}$, followed by seven cycles of 20 s at $94^{\circ} \mathrm{C}, 40$ s at $64^{\circ} \mathrm{C}$ for IL $18-607$ or 60 s at $68^{\circ} \mathrm{C}$ for IL18-137 and $40 \mathrm{~s}$ at $72{ }^{\circ} \mathrm{C}$ and 25 cycles of $20 \mathrm{~s}$ at $94^{\circ} \mathrm{C}$, $40 \mathrm{~s}$ at $57^{\circ} \mathrm{C}$ for IL $18-607$ or $20 \mathrm{~s}$ at $62^{\circ} \mathrm{C}$ for IL $18-137$ and $40 \mathrm{~s}$ at $72{ }^{\circ} \mathrm{C}$, and a final elongation step of $5 \mathrm{~min}$ at $72^{\circ} \mathrm{C}$. The amplified products were analyzed by $1 \%$ agarose gel electrophoresis and stained with ethidium bromide.

\section{Statistical analyses}

Comparisons of clinical and descriptive data of the patients were performed with GraphPad Prism 5.0 software, using non-parametric tests, such as the MannWhitney test, two-sided Fisher exact test for 2 x 2 contingency tables. An exact test that uses the Metropolis algorithm was done to obtain an unbiased estimate of the exact p-value and its standard error using the RXC software (http://www.marksgeneticsoftware.net/rxc.htm). Allele and genotype frequencies were computed using the direct counting method. Hardy-Weinberg equilibrium was tested by an exact test using GENEPOP 3.4 software (Raymond and Rousset, 1995). The haplotype diversity, as well as the standard derivations, was estimated by the ARLEQUIN 3.11 program (Excoffier and Lischer, 2010). Comparisons of allele, haplotype and genotype frequencies were performed by means of the two-sided Fisher's exact test. In all statistical tests, $\mathrm{p}$-values below 0.05 were considered statistically significant.

\section{Results}

\section{Characteristics of the studied population}

Demographic, clinical, laboratorial and histopathological features of transplanted patients are shown in Table 1. According to the histopathological analyses, patients 
were stratified into rejection and non-rejection groups. To evaluate the differential impact of risk factors on graft function we performed univariate analyses encompassing non- immunological (gender, patient age at transplantation, nephropathy leading to renal failure, type of transplantation, donor age and cold ischemia time) and immunological (an-

Table 1 - Demographic, clinical, laboratorial and histopathological features of kidney transplant patients.

\begin{tabular}{|c|c|c|c|}
\hline & With rejection $\mathrm{n}=23$ & Without rejection $\mathrm{n}=59$ & $\mathrm{p}$ value \\
\hline Gender & & & 0.1960 (FET) \\
\hline Male/ Female & $18 / 05$ & $36 / 23$ & \\
\hline Age at transplantation (years) & & & $0.0211(\mathrm{MW})$ \\
\hline Mean & $33.09 \pm 12.44$ & $40.53 \pm 13.01$ & \\
\hline Range & $27.57-38.601$ & $37.01-44.05$ & \\
\hline Nephropathy leading to renal failure & & & 0.8419 (FET) \\
\hline Hypertension & 6 & 17 & \\
\hline Glomerulosclerosis & 0 & 2 & \\
\hline Glomerulonephritis & 5 & 17 & \\
\hline Other & 5 & 11 & \\
\hline Undetermined & 7 & 12 & \\
\hline Antibody reactivity panel (\%) & & & 0.6967 (MW) \\
\hline 0 & 21 & 55 & \\
\hline 1 to 10 & 0 & 0 & \\
\hline 10 to 20 & 0 & 0 & \\
\hline 20 to 30 & 0 & 1 & \\
\hline 30 to 40 & 0 & 1 & \\
\hline 40 to 50 & 1 & 0 & \\
\hline 50 to 60 & 1 & 1 & \\
\hline Mean & $3.29 \pm 7.825$ & $8.29 \pm 20.665$ & \\
\hline Type of transplantation & & & 0.1499 (FET) \\
\hline Deceased / living organ donation & $13 / 08$ & $45 / 12$ & \\
\hline Donor age (years) & & & $0.0624(\mathrm{MW})$ \\
\hline Mean & $43.75 \pm 14.257$ & $33.91 \pm 13.83$ & \\
\hline Range & $36.154-51.346$ & $31.701-40.117$ & \\
\hline Cold ischemia time (h) & & & 0.7623 (MW) \\
\hline Mean & $13.4 \pm 6.021$ & $12.93 \pm 8.675$ & \\
\hline Range & $9.093-17.707$ & $9.265-16.593$ & \\
\hline \multicolumn{4}{|l|}{ Immunossupression } \\
\hline Mycophenolate & $19 / 1$ & $53 / 1$ & $0.470(\mathrm{FET})$ \\
\hline Azathioprine & $1 / 19$ & $2 / 51$ & $1.000(\mathrm{FET})$ \\
\hline Cyclosporine & $6 / 14$ & $11 / 42$ & $0.535(\mathrm{FET})$ \\
\hline Tacrolimus & $14 / 6$ & $42 / 12$ & 0.547 (FET) \\
\hline Sirolimus & $0 / 20$ & $1 / 53$ & $1.000(\mathrm{FET})$ \\
\hline Prednisone & $19 / 1$ & $50 / 1$ & 0.487 (FET) \\
\hline Basiliximab & $7 / 13$ & $16 / 36$ & $0.782(\mathrm{FET})$ \\
\hline Thymoglobulin & $0 / 21$ & $1 / 53$ & $1.000(\mathrm{FET})$ \\
\hline HLA-mismatch & $0.3 \pm 0.6$ & $2.0 \pm 1.0$ & $0.126(\mathrm{MW})$ \\
\hline DR HLA-mismatch & $0.3 \pm 0.6$ & $1.2 \pm 0.4$ & $0.214(\mathrm{MW})$ \\
\hline \multicolumn{4}{|l|}{ Pre-transplant cross-match } \\
\hline Negative / positive & $20 / 1$ & $54 / 0$ & 0.280 (FET) \\
\hline
\end{tabular}

FET: Fisher exact test. MW: Mann-Whitney test. 
tibody reactivity panel, immunosuppressive treatment, HLA-mismatch and pre-transplant cross-match) factors.

Overall, the comparisons between rejection and nonrejection groups revealed non-significant differences, except for the findings that non-rejection patients were older than rejection ones. However, comparisons regarding IL18 alleles, genotypes and haplotypes between patients with and without transplant rejection showed no statistical differences regarding age at transplantation (data not shown).

\section{Creatinine clearance levels and IL18 polymorphism}

The Creatinine values utilized were reached by the calculation of creatinine clearance $(\mathrm{CrCl})$. The kidney transplant patients showed a progressive increase in renal function during the six months follow up of our study, with the most significant increase occurring in patients who had no rejection. The rejection group showed a discrete renal function improvement as shown in Table 2. The $\mathrm{CrCl}$ values when compared with the IL18 genotypes showed no association.

\section{Genotype and allele frequencies of IL18 promoter polymorphisms}

Genotype distribution of both polymorphisms in healthy controls and patients were in Hardy-Weinberg equilibrium (healthy controls: $-607 \mathrm{p}=0.7822,-137$ $\mathrm{p}=1.0000 ;$ Non rejection Group: $-607 \mathrm{p}=0.6108,-137$ $\mathrm{p}=0.6421$; Rejection Group: $-607 \mathrm{p}=0.0584,-137$ $\mathrm{p}=0.0831)$. Allele frequencies and genotype distribution of IL18 polymorphisms $-607 \mathrm{~A} / \mathrm{C}$ and $-137 \mathrm{C} / \mathrm{G}$ in healthy controls and transplant patients are show in Table 3. Haplo-
Table 2 - Kidney function by creatinine clearance $(\mathrm{mL} / \mathrm{min})^{\mathrm{a}}$ of the allograft kidney patients.

\begin{tabular}{lccc}
\hline & $\mathrm{RG}(\mathrm{n}=19)$ & $\mathrm{NRG}(\mathrm{n}=42)$ & $\mathrm{p}$ value \\
\hline 1 month & & & \\
Mean & $43.77 \pm 23.53$ & $53.35 \pm 29.78$ & $0.2589^{\mathrm{b}}$ \\
Range & $32.43-55.11$ & $44.07-62.63$ & \\
3 months & & & \\
Mean & $51.53 \pm 19.69$ & $66.65 \pm 19.32$ & $0.0092^{\mathrm{b}}$ \\
Range & $41.74-61.33$ & $59.90-73.39$ & \\
6 months & & & \\
Mean & $52.84 \pm 12.26$ & $73.79 \pm 20.74$ & $0.0007^{\mathrm{b}}$ \\
Range & $45.43-60.25$ & $66.04-81.53$ & \\
\hline
\end{tabular}

RG: rejection group; NRG: non-rejection group; ${ }^{a}$ estimated glomerular filtration rate calculated with Cockcroft-Gault equation. ${ }^{\mathrm{b}}$ two-sided MannWhitney test.

type analysis demonstrated an increased frequency of the major haplotype $-607 \mathrm{C} /-137 \mathrm{G}$ in kidney transplant patients (odds ratio 2.57, 95\% confidence interval 1.45-4.55, $\mathrm{p}=0.0014$ ) while the minor haplotype $-607 \mathrm{~A} /-137 \mathrm{C}$ was more frequent in healthy controls (odds ratio $0.47,95 \%$ confidence interval 0.24-0.92, $\mathrm{p}=0.0294$ ) (Table 4).

\section{Histopathological analyses}

A total of 49 biopsies were obtained from the 82 kidney transplant recipients. Allograft rejection was present in 23 subjects $(28.05 \%)$ whereas $26(31.71 \%)$ showed no sign of rejection but presented other histological features of renal transplant pathology, i.e. fibrosis, acute tubular necro-

Table 3 - Allele frequencies and genotype distribution (\%) of $I L 18$ polymorphisms $-607 \mathrm{~A} / \mathrm{C}$ and $-137 \mathrm{C} / \mathrm{G}$ in healthy controls and transplant patients.

\begin{tabular}{|c|c|c|c|c|c|c|}
\hline & & Patients & Controls & $\mathrm{p}$ value $^{\mathrm{a}}$ & OR & CI95\% \\
\hline \multicolumn{7}{|l|}{$-607 \mathrm{~A} / \mathrm{C}$} \\
\hline \multirow[t]{2}{*}{ Alleles } & $\mathrm{C}$ & $88(0.603)$ & $252(0.689)$ & $0.0779^{\mathrm{a}}$ & 0.6884 & 0.4607 to 1.023 \\
\hline & A & $58(0.397)$ & $114(0.311)$ & & & \\
\hline \multirow[t]{3}{*}{ Genotype } & $\mathrm{CC}$ & $25(0.342)$ & $81(0.443)$ & 0.1262 & & \\
\hline & $\mathrm{AC}$ & $38(0.521)$ & $90(0.492)$ & & & \\
\hline & AA & $10(0.137)$ & $12(0.065)$ & & & \\
\hline Dominant effect & $\mathrm{CC} v s . \mathrm{AC}+\mathrm{AA}$ & & & $0.1610^{\mathrm{a}}$ & 1.525 & 0.866 to 2.682 \\
\hline Recessive effect & $\mathrm{AA}$ vs. $\mathrm{AC}+\mathrm{CC}$ & & & $0.0832^{a}$ & 0.4421 & 0.1820 to 1.074 \\
\hline \multicolumn{7}{|l|}{$-137 \mathrm{C} / \mathrm{G}$} \\
\hline \multirow[t]{2}{*}{ Alleles } & G & $93(0.628)$ & $269(0.735)$ & $0.0189^{\mathrm{a}}$ & 0.6097 & $0.4061-0.9154$ \\
\hline & $\mathrm{C}$ & $55(0.372)$ & $97(0.265)$ & & & \\
\hline \multirow[t]{3}{*}{ Genotype } & GG & $25(0.337)$ & $99(0.541)$ & 0.0104 & & \\
\hline & CG & $43(0.581)$ & $71(0.388)$ & & & \\
\hline & $\mathrm{CC}$ & $6(0.081)$ & $13(0.071)$ & & & \\
\hline Dominant effect & $\mathrm{GG} v s . \mathrm{CG}+\mathrm{CC}$ & & & $0.0037^{\mathrm{a}}$ & 2.310 & 1.316 to 4.055 \\
\hline Recessive effect & $\mathrm{CC} v s . \mathrm{CG}+\mathrm{GG}$ & & & $0.7949^{\mathrm{a}}$ & 0.8667 & 0.3164 to 2.374 \\
\hline
\end{tabular}

${ }^{a}$ two-sided Fisher exact test. 
Table 4 - Haplotype frequencies (\%) of $I L 18$ promoter in healthy controls and kidney transplant patients.

\begin{tabular}{lccccc}
\hline & Transplant patients & Healthy controls & $\mathrm{p} \mathrm{value}^{\mathrm{a}}$ & OR & IC 95\% \\
\hline$-607 C /-137 G$ & $40(0.588)$ & $65(0.357)$ & 0.0014 & 2.571 & 1.454 to 4.549 \\
$-607 C /-137 C$ & $7(0.103)$ & $19(0.104)$ & 1 & 0.9845 & 0.3941 to 2.459 \\
$-607 A /-137 G$ & $8(0.118)$ & $37(0.203)$ & 0.1401 & 0.5225 & 0.2298 to 1.188 \\
$-607 A /-137 C$ & $13(0.191)$ & $61(0.335)$ & 0.0294 & 0.4689 & 0.2379 to 0.9240 \\
\hline
\end{tabular}

${ }^{\mathrm{a}}$ : chi-square test.

sis, nephritis, interstitial inflammation, glomerulonephritis and relapses of the recipient's underlying kidney disease. Fifteen out of 23 patients exhibited acute rejection (18.3\%) and 8 exhibited chronic rejection (9.8\%). Graft biopsies are not routinely performed in these renal transplanted patients. Prior to biopsy indication, only non-invasive laboratory tests are performed to monitor the graft function. Therefore, this was done only in these 49 patients that presented clinical and/or laboratorial evidence of renal dysfunction.

\section{Discussion}

It is well known that IL-18 has a critical role on inflammation and on the immune responses, enhancing IL-12 driven Th1 immune response and, in synergy with IL-4, stimulating the Th2 cell differentiation profile (Nakanishi et al., 2001). The role of IL-18 has recently been demonstrated in a variety of renal disease processes, including ischemia/reperfusion, autoimmune conditions, infections and malignancies (Leslie and Meldrum, 2008). In addition, IL-18 also has an important role on experimental and human renal transplantation (Parikh et al., 2004; Striz et al., 2005; Wyburn et al., 2005, 2006). Therefore, the analysis of IL18 genetic polymorphisms may improve the understanding of the contribution of this gene to renal transplantation.

The allele variants of the $I L 18$ gene evaluated in this study may affect protein production, since a change from $\mathrm{C}$ to $A$ at position -607 and a change from $\mathrm{G}$ to $\mathrm{C}$ at position -137 have been associated with differential IL18 transcription (Giedraitis et al., 2001). Analysis of the $I L 18$ gene promoter suggested that two single nucleotide variants could cause differences in transcription factor binding. A change from $\mathrm{C}$ to $\mathrm{A}$ at position -607 disrupts a potential binding site for cAMP-responsive element binding protein. A change at position - 137 from $\mathrm{G}$ to $\mathrm{C}$ changes the H4TF-1 nuclear factor binding site to a binding site for an unknown factor found in the GM-CSF promoter (Giedraitis et al., 2001).

The functional significance of these two SNPs has not been elucidated; however, the $-607 \mathrm{C}$ and $-137 \mathrm{G}$ alleles have been associated with higher IL-18 production. In our study, we observed that the frequency of the $-607 \mathrm{C}$ allele was closely similar in kidney transplant patients and in healthy controls, whereas the $-137 \mathrm{G}$ allele at single or double doses was underrepresented in renal transplant patients when compared to controls. On the other hand, the
$-607 \mathrm{C} /-137 \mathrm{G}$ haplotype was overrepresented in kidney transplant patients when compared to controls, whereas the $-607 \mathrm{~A} /-137 \mathrm{C}$ haplotype was underrepresented in patients, indicating that the ensemble of both polymorphic sites may be important for the control of IL18 expression.

It is interesting to note that the transcription factors that regulate IL-18 production may differentially act at the promoter region; for instance, the HTF4-1 transcription factor presents a differential action when targeting the $-137 \mathrm{G} / \mathrm{C}$ polymorphic site (Giedraitis et al., 2001). In addition, multiple sclerosis patients exhibiting the $-607 \mathrm{C} /-137 \mathrm{G}$ haplotype had higher levels of IL18 mRNA, while the $-607 \mathrm{~A} /-137 \mathrm{C}$ haplotype was associated with reduced promoter activity (Giedraitis et al., 2001). Therefore, the study of linkage disequilibrium between $-607 \mathrm{~A} / \mathrm{C},-137 \mathrm{G} / \mathrm{C}$ and eventually other understudied polymorphic sites at the IL 18 promoter region, together with the identification of differentially expressed transcription factors in renal transplanted patients may contribute to the understanding of the role of this gene in transplantation and rejection episodes.

Although we observed no significant differences in terms of IL18 polymorphic sites when rejection patients were compared to non-rejection ones, and when these polymorphic sites were evaluated according to renal function $(\mathrm{ClCr})$, literature studies reported increased frequency of the $-607 \mathrm{C}$ allele in Czech kidney transplant patients who presented delayed onset of graft function (Kolesar et al., 2007) and increased frequency of the -137 GG genotype in Korean patients exhibiting acute kidney rejection (Kim et al., 2008).

In our study, we observed that the -137GG genotype was higher in the control group rather than in transplanted patients. However, we strongly believe that this discrepancy regarding -137GG genotype distribution between Kim's study and ours may be due to racial differences in genotype constitution of the two studied population. Furthermore, the frequency of $-137 \mathrm{GG}, \mathrm{GC}$ and $\mathrm{CC}$ genotypes in other Brazilian cohorts of healthy subjects are similar to those shown in our study, suggesting that the distribution of $-137 \mathrm{GG}$ genotype in our control group is representative of the Brazilian population (Segat et al., 2006, Castelar et al., 2010, Rocha-Júnior et al., 2012). Importantly, this observation gives support to the idea that, although the Brazilian population is genetically heterogeneous when compared to other population, such as the Korean studied by Kim and 
collaborators, it seems to be homogeneous when intrapopulation comparisons are done.

In addition, the combinatorial analysis of alleles at -137 and -607 positions in the context of different clinical conditions, may present different outcomes regarding being a risk factor or presenting a protective function. In support of this hypothesis an increased frequency of -137G/-607A haplotype has been observed in chronic HBV patients (Hirankarn et al., 2007). Similarly, this haplotype was higher in patients with HTLV-1 infection than in healthy subjects, indicating this haplotype as a risk factor for the HTLV-1 infection. On the other hand, protection against HTLV-1 infection was conferred by the $-137 \mathrm{C} /-607 \mathrm{C}$ haplotype, since it was increased in healthy controls (Rocha-Júnior et al., 2012). Furthermore, it was shown in studies involving HIV-1 infection that the haplotype $-137 \mathrm{G} /-607 \mathrm{C}$ was related to susceptibility to this virus (Segat et al., 2006), and the same genotype was associated with protection against lipodystrophy syndrome development in HIV-1 infection (Castelar et al., 2010).

Ideally, the study of the role of $I L 18$ promoter region polymorphisms should include the evaluation of the entire promoter segment to unveil the linkage disequilibrium between all polymorphic sites observed in the segment. In addition, the evaluation of IL-18 serum levels, IL18 expression at the kidney environment, as well as the differential expression profile of the allograft may help to establish relationships among all these factors. In this context, major limitations of this study included the evaluation of only two IL18 promoter region polymorphic sites and lack of concomitant evaluation of IL-18 levels.

Concluding, although no association between IL18 polymorphisms with renal function was observed, the increased frequency of the $I L 18-607 \mathrm{C} /-137 \mathrm{G}$ haplotype (containing both alleles associated with high production of IL-18) in kidney recipients deserves further and larger studies to discern whether or not such association may be due to the underlying kidney disorder or to rejection.

\section{Acknowledgments}

This study was supported by Conselho Nacional de Desenvolvimento Científico e Tecnológico - Brazil.

\section{References}

Castelar L, Silva MM, Castelli EC, Deghaide NH, Mendes-Junior CT, Machado AA, Donadi EA and Fernandes AP (2010) Interleukin-18 and interferon-gamma polymorphisms in Brazilian human immunodeficiency virus-1-infected patients presenting with lipodystrophy syndrome. Tissue Antigens 76:126-30.

Cockcroft DW and Gault MH (1976) Prediction of creatinine clearance from serum creatinine. Nephron 16:31-41.

Excoffier L and Lischer HEL (2010) Arlequin suite ver 3.5: A new series of programs to perform population genetics analyses under Linux and Windows. Mol Eco Res 10:564-567.
Giedraitis V, He B, Huang WX and Hillert J (2001) Cloning and mutation analysis of the human IL-18 promoter: A possible role of polymorphisms in expression regulation. J Neuroimmunol 112:146-152.

Haas SL, Andreas Koch W, Schreiber S, Reinhard I, Koyama N, Singer MV and Böcker U (2005) -137 (G/C) IL-18 promoter polymorphism in patients with inflammatory bowel disease. Scand J Gastroenterol 40:1438-1443.

Hirankarn N, Manonom C, Tangkijvanich P and Poovorawan Y (2007) Association of interleukin-18 gene polymorphism (-607A/A genotype) with susceptibility to chronic hepatitis $\mathrm{B}$ virus infection. Tissue Antigens 70:160-163.

Imboden M, Nicod L, Nieters A, Glaus E, Matyas G, Bircher AJ, Ackermann-Liebrich U, Berger W, Probst-Hensch NM and SAPALDIA Team (2006) The common G-allele of interleukin-18 single-nucleotide polymorphism is a genetic risk factor for atopic asthma. The SAPALDIA Cohort Study. Clin Exp Allergy 36:211-218.

Kim CD, Ryu HM, Choi JY, Choi HJ, Choi HJ, Cho JH, Park SH, Won DI and Kim YL (2008) Association of G-137C IL-18 Promoter polymorphism with acute allograft rejection in renal transplant recipients. Transplantation 86:1610-1614.

Kolesar L, Novota P, Krasna E, Slavcev A, Viklicky O, Honsova E and Striz I (2007) Polymorphism of interleukin-18 promoter influences the onset of kidney graft function after transplantation. Tissue Antigens 70:363-368.

Leslie JA and Meldrum KK (2008) The role of interleukin-18 in renal injury. J Surg Res 145:170-175.

Micallef MJ, Ohtsuki T, Kohno K, Tanabe F, Ushio S, Namba M, Tanimoto T, Torigoe K, Fujii M, Ikeda M, et al. (1996) Interferon- $\gamma$-inducing factor enhances T helper 1 cytokine production by stimulated human T cells: Synergism with interleukin-12 for interferon- $\gamma$ production. Eur J Immunol 26:1647-1651.

Miller SA, Dykes DD and Polesky HF (1988) A simple salting out procedure for extracting DNA from human nucleated cells. Nucleic Acids Res 16:1215.

Mittal RD, Srivastava P, Singh V, Jaiswal P and Kapoor R (2011) Association of common variants of Vascular Endothelial Growth Factor and Interleukin-18 genes with allograft survival in renal transplant recipients of North India. DNA Cell Biol 30:309-315.

Nakamura K, Okamura H, Wada M, Nagata K and Tamura T (1989) Endotoxin-induced serum factor that stimulates gamma interferon production. Infect Immun 57:590-595.

Nakanishi K, Yoshimoto T, Tsutsui H and Okamura H (2001) Interleukin-18 regulates both Th1 and Th2 responses. Annu Rev Immunol 19:423-474.

Novak N, Kruse S, Potreck J, Maintz L, Jenneck C, Weidinger S, Fimmers R and Bieber T (2005) Single nucleotide polymorphisms of the IL18 gene are associated with atopic eczema. J Allergy Clin Immunol 115:828-833.

Okamura H, Tsutsi H, Komatsu T, Yutsudo M, Hakura A, Tanimoto T, Torigoe K, Okura T, Nukada Y, Hattori K, et al. (1995) Coning of a new cytokine that induces IFN-Gamma production by T cells. Nature 378:88-91.

Parikh CR, Jani A, Melnikov VY, Faubel S and Edelstein CL (2004) Urinary interleukin-18 is a marker of human acute tubular necrosis. Am J Kidney Dis 43:405-414. 
Raymond M and Rousset F (1995) Genepop 3.4 software - an updated version of genepop 1.2 - Population-genetics software for exact tests and ecumenicism. J Hered 86:248-249.

Reddy P (2004) Interleukin-18: Recent advances. Curr Opin Hematol 11:405-410.

Rocha-Júnior MC, Haddad R, Cilião Alves DC, de Deus Wagatsuma VM, Mendes-Junior CT, Deghaide NH, Takayanagui OM, Covas DT, Donadi EA and Kashima S (2012) Interleukin-18 and interferon-gamma polymorphisms are implicated on proviral load and susceptibility to human T-lymphotropic virus type 1 infection. Tissue Antigens 80:143-150.

Segat L, Bevilacqua D, Boniotto M, Arraes LC, de Souza PR, de Lima Filho JL and Crovella S (2006) IL-18 gene promoter polymorphism is involved in HIV-1 infection in a Brazilian pediatric population. Immunogenetics 58:471-473.

Solez K, Colvin RB, Racusen LC, Haas M, Sis B, Mengel M, Halloran PF, Baldwin W, Banfi G and Collins AB (2008) Banff 07 classification of renal allograft pathology: Updates and future directions. Am J Transplant 8:753-760.

Striz I, Krasna E, Honsova E, Lacha J, Petrickova K, Jaresova M, Lodererova A, Bohmova R, Valhova S and Slavcev A and
Vitko S (2005) A Interleukin 18 (IL-18) upregulation in acute rejection of kidney allograft. Immunol Lett 99:30-35.

Thompson SR and Humphries SE (2007) Interleukin-18 genetics and inflammatory disease susceptibility. Genes Immun 8:91-99.

Wyburn K, Wu H, Yin J, Jose M, Eris J and Chadban S (2005) Macrophage-derived interleukin-18 in experimental renal allograft rejection. Nephrol Dial Transplant 20:699-706.

Wyburn K, Wu H, Chen G, Yin J, Eris J and Chadban S (2006) Interleukin-18 affects local cytokine expression but does not impact on the development of kidney allograft rejection. Am J Transplant 6:2612-2621.

Yoshimoto T, Takeda K, Tanaka T, Ohkusu K, Kashiwamura S, Okamura H, Akira S and Nakanishi K (1998) IL-12 upregulates IL-18 receptor expression on T cells, Th1 cells, and B cells: Synergism with IL-18 for IFN- $\gamma$ production. J Immunol 161:3400-3407.

Associate Editor: Mara H. Hutz

License information: This is an open-access article distributed under the terms of the Creative Commons Attribution License, which permits unrestricted use, distribution, and reproduction in any medium, provided the original work is properly cited. 